\title{
Synergies and Misalignments in Lean and Green practices: A Logistics Industry Perspective
}

\author{
Vasco Sanchez Rodrigues and Maneesh Kumar \\ Logistics and Operations Management Section, Cardiff Business School, Cardiff University
}

\begin{abstract}
This paper conducts an exploratory case study-based research in three companies to identify the main synergies and misalignments between Lean and Green in the context of a range of distribution networks operating globally, regionally and domestically. The research strategy applied by this study is exploratory multiple case studies in three companies, particularly in the road transport and logistics sector. Semi-structured interviews with fifteen executives from three companies were conducted to identify activities within logistics operations leading to synergies and misalignment between Lean and Green practices. The outcome of the three cases shows that several improvements can be achieved by the simultaneous adoption of Lean and Green. The study contributes to the literature by extending the research in the logistics sector and providing examples from a wide variety of logistics operations on synergies and misalignments between Lean and Green practices. The findings and outcome of this study are a starting point for further research in the logistics sector.
\end{abstract}

Keywords: Lean, Green, Logistics Operations, Synergies, Misalignments

Corresponding author’s email: sanchezrodriguesva1@ @ardiff.ac.uk

\section{Introduction}

In the 1990s, when industry was still new to the world of Lean manufacturing and there was limited noise about environmentally conscious production or manufacturing strategies, Florida (1996) was the first study that discussed how organisations can adapt to environmentally conscious manufacturing by simultaneous or concurrent application of Lean and Green practices. The following innovative and bold statement given by Florida in the 90s, still relevant in 2017, has resulted in traction from the research community in the last decade leading to several publications on synergies and misalignment between Lean and Green practices in the manufacturing setting (Cherrafi et al., 2017; Thanki \& Thakkar, 2016; Ng et al., 2015) and its supply chain (Colicchia et al., 2017; Garza-Reyes et al., 2016).

“... the pursuit of zero defect and zero inventory manufacturing strategies produces spill-over benefits to the environment and creates the context for innovative approaches to emission reduction and pollution prevention, leading in turn toward zero emission manufacturing strategies” (Source: Florida, 1996, p. 101).

The above statement summarises the key focus of Lean is to minimise waste in production and supply chain processes by using innovative approaches to process improvement and close collaboration with supply chains (Negrao et al., 2017). This helps an organisation and its supply chain to inadvertently achieve the environmental objectives of less emission, less resource usage, and less waste (King \& Lenox 2001; Franchetti et al. 2009; Farish, 2009; Carvalho et al. 2011). Thus, the alignment of Lean with Green practice and its methods and tools seems natural (Garza-Reyes et al., 2016; Piercy \& Rich, 2015; Chauhan \& Singh 2012; MartinezJurado \& Moyano- Fuentes, 2014; Dües, et al., 2013; Mollenkopf et al. 2010; Bergmiller \& McCright, 2009). Toyota, the organisation responsible for Lean manufacturing origin, has embedded environmental practises within its improvement philosophy, called Toyota Production System (TPS), and its company strategy. The environmental benefits from 
implementation of TPS, a natural extension or spill-over effect, is demonstrated in energy and water usage reduction by $70 \%$, decrease in emission level by $70 \%$, and total waste per car dropping by $60 \%$ during the manufacturing process of Toyota UK between 1993 and 2007 (Farish, 2009).

Research has demonstrated greater benefits and improvement in the performance of companies from the combined approach of Lean and Green than the standalone approach of either Lean or Green (Carvalho \& Cruz-Machado, 2009; Dües, et al., 2013; Ng et al., 2015). The Lean and Green paradigm targets the same types of waste - inventory, transport (e.g. heated and chilled storage space), by-product or non-product outputs (Franchetti et al., 2009). Nonetheless, Lean synergy with Green is dependent on the type of processes, products and procedures. For example, in a non-repetitive production process characterised by a high degree of demand variability, it will be difficult to find synergistic application of some of the Lean and Green tools (Negrao et al., 2017). Waste reduction and environmental performance can be positively or negatively affected by contextual factors linked to processes, products, and procedures (Negrao et al., 2017; Dües, et al., 2013).

Several studies have discussed the natural synergy between Lean and Green practices (e.g. physical waste reduction, such as unsold stock; lead time compression; and improvement in supplier relationships) and a few examples of misalignment (e.g. non-repetitive production environment characterised by high demand variability) with the majority of studies focusing on manufacturing operations (Aguado et al., 2013; Pampanelli et al., 2014; $\mathrm{Ng}$ et al., 2015; Thanki \& Thakkar, 2016; Cherrafi et al., 2017). There are few studies on integrated Lean and Green practices in upstream operations of the supply chain that focus on closer supplier relationships for developing supplier capabilities in enhancing their economic and environmental performance (Simons \& Mason, 2003; Simpson \& Power, 2005; Mollenkopf et al., 2010; Cabral et al., 2012; Dües, et al., 2013; Piercy \& Rich, 2015).

Limited studies have crossed the organisational boundary to focus on downstream supply chain and, in particular, logistics operations (Colicchia et al., 2017; Garza-Reyes et al., 2016; Tacken et al., 2014; Verrier et al., 2014; Esmemr et al., 2010; Venkat \& Wakeland, 2006), which is an integral part of supply chain activities. This limitation was also identified by a comprehensive and state-of-art literature review conducted by Garza-Reyes (2015) and Mollenkopf et al. (2010). Transportation plays a key role in concurrently achieving the objectives of Lean and Green supply chain practices (Garza-Reyes et al., 2016). Companies across many industries have realised that significant savings can be achieved by effective coordination and green innovation within their logistics operations (Chapman, et al., 2003; Blome et al., 2014). Green initiatives are becoming an important issue for logistics operations as they are one of the main producers of carbon emissions and have a substantially negative impact on the environment. The transport sector is the fastest growing source of $\mathrm{CO}_{2 \mathrm{e}}$ (Abbasi \& Nilsson, 2012; Mollenkopf et al., 2010). From a logistics perspective, fewer transportation activities in the supply chain are conducive to lowering the consumption of natural resources and $\mathrm{CO}_{2 \mathrm{e}}$ emission (Carvalho et al. 2011).

Our study further extends the limited scholarly research in the field of concurrent application of Lean and Green practices within road transport/logistics operations by investigating the practices of three large distribution networks operating globally, regionally and domestically. The objective of the study is aligned with two future research direction questions by Garza- 
Reyes (2015, pg. 27): "How do lean synergies and divergences affect the effectiveness of these initiatives when deployed sequentially or simultaneously? Are the lean and green synergies and divergences the same in every industry?" Thus, the objective of our study is to identify synergies and misalignment between Lean and Green practices within Logistics operations. We also reflect on contextual factors that affect the synergistic relationship between Lean and Green when studying logistics operations. The three documented cases have provided several examples of synergies and misalignments between Lean and Green practices under different operational settings and demonstrate how LSPs can make use of innovative processes, procedures, and technologies to efficiently conduct their operations with minimal environmental impact. The three case companies provide sufficient evidence and examples for logistics managers to undertake empirical integration of two practices.

The paper proceeds by discussing the main gaps found in the literature, followed by the methodology section. Subsequently, the findings section presents analysis of the data collected from the three case studies. Furthermore, the findings are discussed in the context of supply chain literature on lean and green. The conclusions section discusses the main contribution and further research opportunities derived from the research.

\section{Literature Review}

Constant pressure from customers and other stakeholders has forced companies to restructure their operations and supply chain practices, to shift the focus from economic performance to environmental performance, in the pursuit of sustainable competitive advantage (Capineri et al., 2006; Martinez-Jurado \& Moyano-Fuentes, 2014). Lean and Green practices have emerged as one of the potential solutions to address economic and environmental performance simultaneously within manufacturing operations and supply chain activities of companies. Manufacturers can concurrently gain economic benefit and enhancement in quality, reduction in product costs and manufacturing cycle time by adopting Lean principles (Cudney \& Elrod, 2011). However, Lean and Green practices, as part of a company's manufacturing strategy, are no longer an order winner but have become an order qualifier (Slack et al., 2013) for successful companies to maintain their competitive advantage. Companies excelling in the three dimensions of efficiency, effectiveness and sustainability can only thrive in this global economy and fierce competition (Garza-Reyes, 2015).

Lean supply chain management is mainly focused on maximising productivity by increasing output per unit of input, conserving resources, reducing waste and minimizing costs, whereas green supply chain management is concerned with mitigating the impact of supply chain on the environment (Franchetti et al., 2009; Carvalho et al., 2011; King \& Lenox 2001; Mollenkopf et al., 2010; Garza-Reyes, 2015; Martinez-Jurado \& Moyano-Fuentes, 2014; Dües et al., 2013). As supply chains are becoming ever more complex and longer, it is far more difficult to achieve economic and environmental objectives simultaneously through standalone Lean practices (Mollenkopf, et al., 2010). Companies need to balance their focus congruently on positive economic performance and triple bottom line of sustainability (Cherrafi et al., 2017; Alves \& Alves, 2015). Supply chains must become greener to satisfy current demands from legislation and their customers (Garza-Reyes, 2015; Piercy \& Rich, 2015). An increasing number of firms tend to adopt Green practices in the supply chain to obtain corporate benefits and market-share objectives by reducing environmental risk and enhancing ecological efficiency (Zhu et al., 2008; Martinez-Jurado \& Moyano-Fuentes, 2014). 
Best practices from industry confirm that organisations simultaneously implementing Lean and Green can perform better than a standalone approach of Lean or Green (Cherrafi et al., 2017; $\mathrm{Ng}$ et al., 2015; Piercy \& Rich, 2015). Organisations can only perceive the full potential and greater benefits of Lean and Green when these are implemented simultaneously (Bergmiller \& McCright, 2009). Research into integrated Lean and Green practices have emerged significantly in the last five years (Cherrafi et al., 2017; Tomelero et al., 2017; Piercy \& Rich, 2015; Garza-Reyes, 2015; Martinez-Jurado \& Moyano-Fuentes, 2014; Dües et al., 2013). Most recent publications are either conceptual papers (Garza-Reyes, 2015; Martinez-Jurado \& Moyano-Fuentes, 2014; Dües et al., 2013) or examinations of the application of Lean-Green practices within manufacturing operations (Cherrafi et al., 2017; Tomelero et al., 2017). The current literature on Lean and Green focuses largely on the synergies and misalignments between Lean and Green. For example, Lean and Green practices can have synergies in terms of physical waste reduction (e.g. unsold stock), lead time compression, and improvement in supplier relationships (Dües, et al., 2013; Garza-Reyes, 2015; Martinez-Jurado \& MoyanoFuentes, 2014). Companies implementing Lean to reduce waste from their processes (King \& Lenox, 2001; Mollenkopf et al., 2010; Carvalho et al., 2011) have also witnessed improvements in environmental metrics, such as reduction in energy and water usage (Franchetti et al., 2009; Carvalho et al., 2011). Table 1 and 2 provide more description of synergies and misalignments between Lean and Green practices.

Table 1 - Lean and Green Synergies

\begin{tabular}{|c|c|c|c|c|}
\hline \multirow{2}{*}{$\begin{array}{l}\text { Synergetic } \\
\text { Factors } \\
\text { (Conceptual } \\
\text { papers) }\end{array}$} & \multirow[t]{2}{*}{ Description } & \multicolumn{3}{|c|}{ Application In } \\
\hline & & Mfg. & $\begin{array}{l}\text { Supply } \\
\text { Chain }\end{array}$ & Logistics \\
\hline $\begin{array}{l}\text { Waste reduction } \\
\text { (Dües, et al., } \\
\text { 2013; Garza- } \\
\text { Reyes, 2015) }\end{array}$ & $\begin{array}{l}\text { Lean and Green practices are effective in } \\
\text { minimising raw material wastes, WIP, and finished } \\
\text { good inventory wastes; At the same time } \\
\text { integrated approach also helps in minimising waste } \\
\text { due to unnecessary electricity and water } \\
\text { consumption. The streamlining of business } \\
\text { processes simultaneously impacts on efficiency } \\
\text { and environmental metrics such as improved } \\
\text { productivity, lead time reduction, and reduction in } \\
\mathrm{CO}_{2 \mathrm{e}} \text { emissions. }\end{array}$ & $\begin{array}{l}\text { Farish, } \\
2009 ; \\
\text { Cheraffi } \\
\text { et al., } \\
2017\end{array}$ & $\begin{array}{l}\text { Piercy \& } \\
\text { Rich, } \\
2015\end{array}$ & $\begin{array}{l}\text { Colicchia } \\
\text { et al., } \\
2017\end{array}$ \\
\hline $\begin{array}{l}\text { Improvement in } \\
\text { key performance } \\
\text { indicators at } \\
\text { operations and } \\
\text { supply chain } \\
\text { level (Dües, et } \\
\text { al., 2013; } \\
\text { Garza-Reyes, } \\
\text { 2015) }\end{array}$ & $\begin{array}{l}\text { Lean and Green directly impact on operations and } \\
\text { supply chain KPIs such as reduction in inventory } \\
\text { by having effective utilisation of raw material and } \\
\text { reducing redundant materials to free up space; } \\
\text { shorten lead time of delivery with an improvement } \\
\text { in cost and reduction in } \mathrm{CO}_{2 \mathrm{e}} \text { emission; minimised } \\
\text { material handling during manufacturing and } \\
\text { reduced replenishment frequency to decrease fuel } \\
\text { consumption and } \mathrm{CO}_{2 \mathrm{e}} \text { emissions. }\end{array}$ & $\begin{array}{l}\text { Franchetti } \\
\text { et al., } \\
2009 ; \\
\text { Cheraffi } \\
\text { et al., } \\
2017\end{array}$ & $\begin{array}{l}\text { Piercy \& } \\
\text { Rich, } \\
2015\end{array}$ & $\begin{array}{l}\text { Garza- } \\
\text { Reyes et } \\
\text { al., } 2016\end{array}$ \\
\hline $\begin{array}{l}\text { Conserve } \\
\text { resources by } \\
\text { focusing on } \\
\text { product design } \\
\text { (Dües, et al., } \\
2013 \text { ) }\end{array}$ & $\begin{array}{l}\text { Lean and Green integration requires product } \\
\text { design/ R\&D functions joining hands with } \\
\text { operations and supply chain functions to maximise } \\
\text { product performance and minimise cost; at the } \\
\text { same time eco-design of product should take into } \\
\text { consideration recycling and remanufacturing } \\
\text { alternatives to maximise the re-use of natural } \\
\text { resources }\end{array}$ & $\begin{array}{l}\text { Dhingra } \\
\text { et al., } \\
2014 ; \\
\text { Figge \& } \\
\text { Hahn, } \\
2012\end{array}$ & & $\begin{array}{l}\text { Colicchia } \\
\text { et al., } \\
2017\end{array}$ \\
\hline
\end{tabular}




\begin{tabular}{|c|c|c|c|c|}
\hline \multirow{2}{*}{$\begin{array}{l}\text { Synergetic } \\
\text { Factors } \\
\text { (Conceptual } \\
\text { papers) }\end{array}$} & \multirow[t]{2}{*}{ Description } & \multicolumn{3}{|c|}{ Application In } \\
\hline & & Mfg. & $\begin{array}{l}\text { Supply } \\
\text { Chain }\end{array}$ & Logistics \\
\hline $\begin{array}{l}\text { Improve } \\
\text { visibility and } \\
\text { supply chain } \\
\text { relationship } \\
\text { (Martinez- } \\
\text { Jurado \& } \\
\text { Moyano- } \\
\text { Fuentes, 2014; } \\
\text { Dües, et al., } \\
\text { 2013;Mollenkopf } \\
\text { et al., 2010) }\end{array}$ & $\begin{array}{l}\text { The integration of Lean and Green is only possible } \\
\text { if supply chain visibility is improved significantly } \\
\text { by close collaboration among suppliers and } \\
\text { customers; this requires reciprocal, trusting, long- } \\
\text { term relationships between the customer and a few } \\
\text { selected suppliers; at the same time sharing } \\
\text { knowledge on Lean \& Green practices with } \\
\text { suppliers to improve their capabilities; good } \\
\text { relationship with customers will result in reduction } \\
\text { in order variability, thereby having impact on } \\
\text { inventory level, minimise logistics cost and } \mathrm{CO}_{2 \mathrm{e}} \\
\text { emissions }\end{array}$ & & $\begin{array}{l}\text { Piercy \& } \\
\text { Rich, } \\
2015 ; \\
\text { Simpson } \\
\& \\
\text { Power, } \\
2005\end{array}$ & $\begin{array}{l}\text { Colicchia } \\
\text { et al., } \\
2017 ; \\
\text { Garza- } \\
\text { Reyes et } \\
\text { al., } 2016\end{array}$ \\
\hline $\begin{array}{l}\text { Process } \\
\text { innovation } \\
\text { (Negrao et al., } \\
\text { 2017) }\end{array}$ & $\begin{array}{l}\text { Integrated approach leads to incremental } \\
\text { innovation in operations and supply chain } \\
\text { performance; organisations can also realise radical } \\
\text { innovation from integrated approach by } \\
\text { application of latest technology in operations and } \\
\text { supply chain practices including hybrid or electric } \\
\text { vehicles; incremental innovation in processes } \\
\text { achieved through Lean projects directly impact on } \\
\text { environmental metrics including reduction in } \\
\text { energy, raw material, and water consumptions. }\end{array}$ & $\begin{array}{l}\text { Florida, } \\
\text { 1996; } \\
\text { Franchetti } \\
\text { et al., } \\
2009 ; \\
\text { Cheraffi } \\
\text { et al., } \\
2017\end{array}$ & $\begin{array}{l}\text { Piercy \& } \\
\text { Rich, } \\
\text { 2015; }\end{array}$ & $\begin{array}{l}\text { Colicchia } \\
\text { et al., } \\
\text { 2017; }\end{array}$ \\
\hline
\end{tabular}

In spite of sharing common goals, there are some misalignments between Lean and Green practices, see Table 2. One of the explicit misalignments is the focus on carbon reduction in Green practices which is not possible to achieve if companies follow just in time (JIT) practices, one of the Lean pillars, with more frequent replenishment from suppliers (Rothenberg, et al., 2001). However, technological and managerial solutions can be applied to realise substantial reductions in the environmental impact of supply chains (Garnett, 2009).

Table 2 - Lean and Green Misalignment

\begin{tabular}{|c|c|c|c|c|}
\hline \multirow{2}{*}{$\begin{array}{l}\text { Misaligment Factors } \\
\text { (Conceptual papers) }\end{array}$} & \multirow[t]{2}{*}{ Description } & \multicolumn{3}{|c|}{ Application In } \\
\hline & & Mfg. & $\begin{array}{l}\text { Supply } \\
\text { Chain }\end{array}$ & Logistics \\
\hline $\begin{array}{l}\text { Cost as a key barrier to } \\
\text { Lean and Green } \\
\text { integration } \\
\text { (Mollenkopf et al., } \\
\text { 2010; Garza-Reyes, } \\
\text { 2015) }\end{array}$ & $\begin{array}{l}\text { Simultaneously achieving Lean and Green } \\
\text { objectives sometimes can prove expensive } \\
\text { in the short-term, when companies need to } \\
\text { make significant investment upfront in } \\
\text { processes and technologies, e.g. upgrading } \\
\text { to electric or hybrid vehicle to reduce } \\
\mathrm{CO}_{2 \mathrm{e}} \text { emission; new machines on the } \\
\text { shop-floor that are more energy efficient. }\end{array}$ & $\begin{array}{l}\text { Farish, } \\
\text { 2009; }\end{array}$ & $\begin{array}{l}\text { Venkat \& } \\
\text { Wakeland, } \\
2006\end{array}$ & $\begin{array}{l}\text { Tacken et } \\
\text { al., 2014; } \\
\text { Colicchia } \\
\text { et al., } \\
2017\end{array}$ \\
\hline $\begin{array}{l}\text { Just-in-Time (Lean } \\
\text { approach) and carbon } \\
\text { emissions stay in } \\
\text { conflict (Dües, et al., } \\
\text { 2013; Garza- } \\
\text { Reyes,2015) }\end{array}$ & $\begin{array}{l}\text { JIT approach requires delivery in small } \\
\text { batches but at more regular interval (at the } \\
\text { right time, place, and quantity). However, } \\
\text { more frequent replenishment may help to } \\
\text { reduce inventory at the customer end but } \\
\text { contributes significantly to } \mathrm{CO}_{2 \mathrm{e}} \text { emission. }\end{array}$ & $\begin{array}{l}\text { Rothenberg, } \\
\text { et al., } 2001\end{array}$ & $\begin{array}{l}\text { Piercy \& } \\
\text { Rich, } \\
2015\end{array}$ & $\begin{array}{l}\text { Tacken et } \\
\text { al., 2014; } \\
\text { Garza- } \\
\text { Reyes et } \\
\text { al., } 2016\end{array}$ \\
\hline
\end{tabular}




\begin{tabular}{|c|c|c|c|c|}
\hline \multirow{2}{*}{$\begin{array}{l}\text { Misaligment Factors } \\
\text { (Conceptual papers) }\end{array}$} & \multirow[t]{2}{*}{ Description } & \multicolumn{3}{|c|}{ Application In } \\
\hline & & Mfg. & $\begin{array}{l}\text { Supply } \\
\text { Chain }\end{array}$ & Logistics \\
\hline $\begin{array}{l}\text { Contradictions in } \\
\text { waste: time \& stock } \\
\text { versus } \mathrm{CO}_{2 \mathrm{e}} \text { and } \\
\text { customer (Dües, et al., } \\
\text { 2013; Simpson \& } \\
\text { Power, 2005) }\end{array}$ & $\begin{array}{l}\text { This is directly linked to JIT contradiction } \\
\text { - JIT delivery helps in reducing inventory } \\
\text { and results in time compression. However, } \\
\text { such objectives are achieved by } \\
\text { compromising on other environmental } \\
\text { metrics such as } \mathrm{CO}_{2 \mathrm{e}} \text { emission. In order to } \\
\text { adhere to customer demand, suppliers } \\
\text { need to do frequent replenishments. } \\
\text { Customers' support is required to } \\
\text { overcome this contradiction. }\end{array}$ & & $\begin{array}{l}\text { Venkat \& } \\
\text { Wakeland, } \\
2006\end{array}$ & $\begin{array}{l}\text { Colicchia } \\
\text { et al., } \\
2017 ; \\
\text { Garza- } \\
\text { Reyes et } \\
\text { al., } 2016\end{array}$ \\
\hline $\begin{array}{l}\text { Perspective of the } \\
\text { nature of the } \\
\text { environment \& } \\
\text { conflicting customer } \\
\text { preferences (Dües, et } \\
\text { al., 2013) }\end{array}$ & $\begin{array}{l}\text { Lean views the environment as a provider } \\
\text { of valuable resource for maximising } \\
\text { productivity by increasing output per unit } \\
\text { of input; However, Green views the } \\
\text { environment as a restriction on designing } \\
\text { and producing product and services due to } \\
\text { scarcity of natural resources, which are } \\
\text { depleting at a faster rate. }\end{array}$ & $\begin{array}{l}\text { Franchetti, } \\
\text { et al., 2009; } \\
\text { Dhingra et } \\
\text { al., } 2014\end{array}$ & & $\begin{array}{l}\text { Tacken et } \\
\text { al., } 2014\end{array}$ \\
\hline $\begin{array}{l}\text { Change management } \\
\text { (Dües, et al., } 2013 \text {;; } \\
\text { Martinez-Jurado \& } \\
\text { Moyano-Fuentes, } \\
\text { 2014) }\end{array}$ & $\begin{array}{l}\text { To see the real-benefit from integrated } \\
\text { approach, organisations need to make } \\
\text { some significant investment upfront in the } \\
\text { short-term and see the return on } \\
\text { investment in the long-term. However, } \\
\text { there are many senior management teams } \\
\text { that are not ready to wait for long-term to } \\
\text { see the benefit from integrated approach } \\
\text { and thus sceptical about making more } \\
\text { investment in Lean and Green approach. }\end{array}$ & $\begin{array}{l}\text { Florida, } \\
\text { 1996; } \\
\text { Franchetti } \\
\text { et al., 2009; } \\
\text { Cheraffi et } \\
\text { al., } 2017\end{array}$ & $\begin{array}{l}\text { Piercy \& } \\
\text { Rich, } \\
2015 ;\end{array}$ & $\begin{array}{l}\text { Colicchia } \\
\text { et al., } \\
\text { 2017; }\end{array}$ \\
\hline
\end{tabular}

In addition to challenges related to JIT policies, insufficient supply chain visibility can lead to unnecessary inefficiencies in inventory holding and transportation operations, as found by $\mathrm{Ye}$ $\& \mathrm{Wu}$ (2015) and Sanchez Rodrigues et al. (2015). Another main difference between Lean and Green lies in how they see the environment. Lean views the environment as a provider of valuable resource for maximising productivity by increasing output per unit of input (Dhingra, et al., 2014). However, Green views the environment as a restriction on designing and producing product and services due to scarcity of natural resources, which are depleting at a faster rate. Therefore, there is a potential conflict between implementing Lean principles and the adoption of environmentally friendly practices (Franchetti, et al., 2009). Although it has been shown that painting cars in batches of the same colour can reduce emissions, this stands in conflict with JIT principles (Rothenberg, et al., 2001).

There is a dearth of empirical research on how Lean and Green practices could be incorporated to improve the efficiency and effectiveness of logistics operations. In the case of logistics operations, the overall aim is to optimise all activities along the supply chain from the final customer's point-of-view (Martinez-Jurado \& Moyano-Fuentes, 2014). Inefficient logistics operations are less cost-effective and have a substantially negative impact on the environment as they are the main producers of carbon emissions (Abbasi \& Nilsson, 2012).

Applying Lean to logistics operations reduces the waste or inefficiencies that lie in logistics systems, so that small/incremental or breakthrough/ radical improvements can then be made in the development of a Lean logistics system (Jones et al., 1997). Lean logistics refers to the superior ability to design and administer systems to control movement and geographical 
positioning of raw materials, work-in-process, and finished inventories at the lowest cost ( $\mathrm{Wu}$, 2004). Lean logistics is also about minimising waste generated by logistics networks, such as excessive inventory, unnecessary miles run by vehicles, under-utilised vehicles and delays in the delivery process (Garza-Reyes et al., 2016). Lean has caused a transformation in the UK retail logistics sector since efficiency improvements were enacted and e-commerce initiatives and environmental factors accommodated (Fernie et al., 2000). Many of these Lean metrics are synergistic with Green metrics, since reduction in fuel and electricity consumption is central for Lean and Green (Dües, et al., 2013; Garza-Reyes, 2015). These two paradigms are aligned when one looks at logistics functions in isolation; for example, efficient transport operations can optimise Tonne-Km, and, as a result, reduce cost and $\mathrm{CO}_{2 \mathrm{e}}$ emissions. Thus, it is imperative to understand how concurrent adoption of Lean and Green practices in logistics operations is aligned to achieve common objectives of waste reduction and positive impact on environment.

To date, limited papers (Colicchia et al., 2017; Garza-Reyes et al., 2016; Tacken et al., 2014; Verrier et al., 2014; Esmemr et al., 2010; Venkat \& Wakeland, 2006) discuss the simultaneous application of Lean and Green within the logistics sector. Venkat \& Wakeland's (2006) study suggested organisations transit from far supply chain to small regional supply chain to achieve the objectives of Lean and Green simultaneously, i.e. less inventory, less waste, and fewer emissions from transport. Furthermore, they emphasised efficient transport mode and sharing truck load with other companies as a way to minimise $\mathrm{CO}_{2 \mathrm{e}}$ emissions. Esmemr et al's (2010) study had limited focus on port logistics for effective container handling and Varrier et al's (2014) study superficially focused on two small logistics service providers (LSP) among another 19 industrial companies in their sample. A single case study by Garza-Reyes et al (2016) on simultaneous application of Lean and Green in road transport and logistics sector resulted in development of a novel tool termed sustainable transportation value stream map (STVSM) that improves the operational efficiency and environmental performance of road transport operations. Colicchia et al. (2017) also gathered evidence on how supply chains can become Lean and Green through the adoption of intermodal transport solutions, volume consolidation, and inter-company collaboration. This finding is aligned with the study by Tacken et al. (2014), which identifies several measures that logistics operations can apply to be Green and Lean, e.g. modal shift, vehicles routing optimisation, volume consolidation, increased back haulage, and inter-company collaboration. However, there are several Green measures that can be applied to logistics networks which can increase the cost of logistics operations, such as the adoption of alternative fuels and hybrid engines, particularly when an organisation does not allow for longer payback periods for their Green investments.

Our paper further attempts to highlight the synergies and misalignments when applying Lean and Green practices in three case companies within the logistics sector, and in particular within road transport. The next section presents the method adopted to conduct the exploratory research on this topic.

\section{Methodology}

The research strategy applied by this study is exploratory multiple case studies in three companies. Robson (2002) deems case study as a strategy for empirical investigation of a given issue within its actual circumstance, using subsistent evidence sourced from different origins. Compared with experiment or survey, also based on practical actions, case study possesses greater freedom on context and on variables (Yin 2014). The resultant theory out of an inductive case-study approach is often novel, testable and empirically valid (Eisenhardt, 1989; Eisenhardt \& Graebner, 2007). Case studies, concentrating on the practical performance of different firms, conclude the individual findings and establish a theory, based on practical cases, being seen as an inductive approach (Meridith, 1998). Three leading companies in the 
UK distribution network were selected using convenience sampling method; namely, two global logistics service providers (LSPs) and one retail company with a very large logistics network. Each company had minimum exposure of 5-6 years in Lean and Green practice deployment within their logistics operations. The interviews were conducted in the UK based locations of the companies, with a focus on road transport/logistics operations.

Company A runs international logistics services; company B runs a wider range of services, running global, regional and domestic distribution networks; and company $\mathrm{C}$ is a grocery retailer, based in the UK, which runs their own in-house domestic distribution network. Company A is a global LSP which is an associate company of one of the largest shipping companies in the world (headquarters in Japan) and mainly run international logistics services in a range of sectors. Company B is a German based worldwide operating logistics service provider and belongs to one of the largest organisations worldwide. The companies have been chosen because of their constant pursuit towards continuous improvement by applying Lean and Green practices. In particular, company B pursues a radical Green strategy within its cooperation and also tries to enhance customer awareness regarding Green issues. Company $\mathrm{C}$ has an in-house distribution network with very efficient warehousing and transport operations that together deliver grocery products from distribution centres and local warehouses to customers' homes.

This study is exploratory in nature, which justifies the use of semi-structured interviews as data collection method. A range of managers from three cases were interviewed after being selected as suitable for the research subject due to their professional experience and knowledge, either on the topic Lean or Green or both, see Table 3. Most interviewees have more than 15 years' experience of working in the logistics industry and have exposure to Lean and Green initiatives implemented within the case organisation. Most of the conveniently selected interviewees possessed a good understanding of Green initiatives undertaken by the case organisation, given the nature of their job profile, and have either led Lean implementation or been part of a project team implementing Lean. The experience column in Table 3 reflects their experience of working for the selected case organisation. This provides an opportunity to collect data that included a wide range of perspectives, so the quality of the data collection could be enhanced. Table 3 shows a brief background on the practitioners interviewed in case studies A, B and C.

The interview protocol was developed for each role and was influenced by past literature (Garza-Reyes et al., 2016; Piercy \& Rich, 2015; Cherrafi et al., 2017; Colicchia et al., 2017; Tacken et al., 2014; Verrier et al., 2014; Esmemr et al., 2010; Venkat \& Wakeland, 2006). The questions were pilot tested with two academics and one practitioner. The comments from the pilot study were incorporated to modify the interview protocol. A snapshot of questions asked in the interview protocol is presented in Appendix 1. More detailed interview protocol for each role can be obtained from the authors. Mostly indirect questions were asked that led to an understanding of synergies and misalignments, rather than directly asking questions on the topic. The semi-structured interviews were conducted by both authors, either face to face or by telephonic conversation. The interviews were customised, depending upon the position of the interviewees. The semi-structured nature of the interview allowed authors further 'probing'. As recommended by Saunders et al. (2012), semi-structured interviews are used to ensure rigour as well as depth in the qualitative data collected in the case studies. 
Table 3 - Brief background on the practitioners interviewed in Cases A, B and C

\begin{tabular}{|c|c|c|c|}
\hline Case & Interviewee & Role & $\begin{array}{c}\text { Experience in } \\
\text { the current } \\
\text { company } \\
\text { (years) }\end{array}$ \\
\hline \multirow{4}{*}{ A } & 1 & European Procurement Manager & 2 \\
\cline { 2 - 4 } & 2 & Contract Manager & 8 \\
\cline { 2 - 4 } & 3 & General Manager Healthcare & 8 \\
\cline { 2 - 4 } & 4 & General Manager & 14 \\
\cline { 2 - 4 } & 5 & European Operations Manager & 6 \\
\cline { 2 - 4 } & 6 & Relationship Manager & 1 \\
\hline \multirow{4}{*}{ B } & 7 & Market Carrier Coordinator & 3 \\
\cline { 2 - 4 } & 1 & Operations Excellence Manager Automotive Sector & 4 \\
\cline { 2 - 4 } & 2 & Chief Operations Officer UK \& Ireland & 10 \\
\cline { 2 - 4 } & 3 & General Manager Urban Consolidation & 15 \\
\hline C & 4 & Vice-president of Transport Strategy and Green & 5 \\
\cline { 2 - 4 } & 1 & Distribution Director & 5 \\
\cline { 2 - 4 } & 2 & General Manager & 4 \\
\cline { 2 - 4 } & 3 & Supply Chain Director & 6 \\
\hline
\end{tabular}

The interviews lasted between 60 and 90 minutes. Each interview was digitally recorded and jointly conducted by the authors to allow note taking. Interviews were later transcribed and emailed to interviewees to ascertain the facts or identify any errors in the transcript. The qualitative data were analysed by identifying the themes linked to synergies and misalignments in Lean and Green applications across the three companies. First analysis of each case was conducted, followed by cross case comparison, as supported by Yin (2014) and Eisenhardt (1989). The use of protocol helped in conducting thematic analysis of qualitative data, thereby drawing out emerging themes from the data (Miles \& Huberman, 1994; Yin, 2014).

\section{Findings gathered from the case studies}

This section presents the findings gathered from Cases A, B and C.

\section{Case study A - Synergies and misalignments between Green and Lean}

The views gathered during case study A on synergies and misalignments between Green and Lean are diverse. Interview 2,3,5,6, and 7 stated that Lean and Green initiatives can lead to cost savings and mitigation of environmental impacts, particularly $\mathrm{CO}_{2 \mathrm{e}}$ emissions, whereas Interviewees 1 and 4 mentioned that Lean and Green adoption can influence quality in a positive, or at least, neutral way. According to Interviewees 2, 5 and 7, Green and Lean go hand in hand. Interviewee 2 confirmed that reduction in $\mathrm{CO}_{2 \mathrm{e}}$ emissions is achieved through reduction in vehicle movement and improved vehicle utilisation. This statement was further supported by Interviewee 5 stating "Green and Lean go hand in hand in everything, since everything company A has done to improve efficiency of our operations in terms of minimising distance run by vehicles and maximising vehicle fill rate has led to carbon reduction". Several examples of efficiency and environmental improvement practices linked to simultaneous 
application of Lean and Green in the European market was provided by Interviewee 5, such as implementation of live track-and-trace transport planning systems, merging supplier collections with customer deliveries to reduce empty running, and outsourcing runs in situations where a sub-contractor is able to execute trips in a more efficient manner, which have resulted in reductions in cost and $\mathrm{CO}_{2 \mathrm{e}}$ emissions. However, Interviewees 2, 5, and 7 emphasised that Green is a secondary effect of cost-reduction solutions, since a better optimised logistics network through Lean tools application is economically driven and brings a reduction in the total miles run by vehicles, maximisation of vehicle utilisation and minimisation of vehicle mileage. Interviewee 7 confirmed this point by stating that in road freight transport, Green and Lean do not contradict each other. In his opinion, the vast majority of Lean and Green initiatives lead to cost savings. The following statement from Interviewee 7 further confirms this argument: "Fuel-efficient vehicles can bring a reduction in fuel cost and $\mathrm{CO}_{2 e}$ emissions and the required investment can be paid in a period of about three years".

According to Interviewees 3, 4, 5 and 7, one of the main objectives when implementing Lean and Green simultaneously in supply chains is the reduction of packaging. As Interviewee 4 stated "... packaging represents $70 \%$ of the weight of a pallet of the light perishable products we distribute". Therefore, reductions in packaging can result in reductions in packaging and freight transport costs, waste and $\mathrm{CO}_{2}$, since material and vehicle running cost (through an increase in load density) can be reduced dramatically; thus, it is clear that, in the case of packaging, Lean and Green are synergistic. The concept of postponement, popular in supply chain literature, and application in packaging operations can greatly benefit the client, customer, and LSPs, as suggested by Interviewee 5: “... if the size of boxes used for packaging individual items are increased to accommodate more items per box, there could be a significant reduction in the usage of cardboard material, reducing packaging waste and cost at the same time; and, in some of our customers' supply chain, semi-finished components are transported in bulk to be packed at a point closer to the market, which has brought huge benefits in terms of reductions in product obsolescence and warehousing KWATs per square metre, and maximisation of freight transport Tonne-Km".

In contrast, it was found that in some instances Lean and Green are not always aligned in relation to customer demand and stock replenishment, and logistics-based quality assurance systems. As Interviewee 3 stated, “... in case of stock shortages, the customer can order replenishments of small stock quantities to our company; therefore, one or two pallets might need to be moved in detriment of vehicle utilisation", which has a substantial impact on $\mathrm{CO}_{2 \mathrm{e}}$ emissions but aligns with Lean practice of JIT delivery in small batches. Furthermore, as Interviewee 6 has stated, there are also certain changes in terms of quality and service that are necessary, but will increase $\mathrm{CO}_{2 \mathrm{e}}$ emissions and costs, e.g. refrigeration or heating systems in warehouses and vehicles.

The research identified several misalignments that company A faced when implementing Green and Lean simultaneously. According to all interviewees, the implementation of radical Green logistics solutions can generate sharp increases in cost, especially when the technology to be implemented is not sufficiently mature. These increases the payback period of the technology to go beyond the permissible payback period of any investment, three to five years. Also, the size and revenue of the logistics firms impact on their decisions to invest in Greener transportation, as return on investment period will be of long duration that may impact on survival of small carriers. According to Interviewee 1, “... a substantial initial investment is often needed to implement Green and Lean activities". Interviewee 4 stated that "... Green as an objective is not put ahead over the financial results of company A when implementing Lean 
and Green simultaneously". Nonetheless, the long-term benefits of such investment will overcome the short-term focus on reducing operations cost, as Interviewee 7 stated: "... the adoption of Green practices in logistics can generate efficiency gains; for instance, even though the adoption of hybrid vehicle and electric vehicle technologies require significant initial investment, these types of technologies can make logistics most cost-effective after the investment is paid off by the savings obtained from improvements in fuel efficiency".

Although the usage of hybrid vehicles can reduce the carbon footprint of transport operations and, as a result, the product carbon footprint, this type of vehicle technology does not have an impact on product quality. Because hybrid and electric vehicles can significantly reduce the running cost of vehicles through fuel consumption savings, these types of technologies can consequently generate reductions in $\mathrm{CO}_{2 \mathrm{e}}$ emissions. Furthermore, according to Interviewee 5, "Green initiatives do not have an impact on the time dimension of performance in supply chains. However, the possible increase in delivery times required when moving cargo using Greener modes, such as water or rail, is just not acceptable to the customer". The same can be said regarding the potential, negative effects of shortsea shipping on inventory levels. According to Interviewee 4, the quality element linked to product life and perishability is paramount when an LSP is scheduling deliveries for multiple locations. The consolidation of customers' orders for multiple locations is done as long as it does not affect the target delivery time set by customers.

Another misalignment, identified by Interviewee 1, is linked to visibility and transparency when measuring Green and Lean performance of processes and activities across supply chains. Interviewee 1 explained that carriers, moving products on behalf of company A, often do not give sufficient visibility of the volume that needs to move; and such problems can create difficulty for company A to react and respond to uncertainty generated at their customer warehouses or their customer's customer outlets. In some cases, it is not known if vehicles used for deliveries are fully or partially loaded; such visibility barrier between company A and its carriers make it difficult to drive efficiency gains external to the company A networks. Consequently, any consolidation opportunity is missed, and it is difficult to simulate collaborative transport network models that could seek to maximise vehicle utilisation through freight consolidation. Interviewee 3 also confirmed that full access to the characteristics of the volume orders is paramount to undertake the planning and execution of deliveries to customers in an optimal manner.

According to Interviewees 3 and 6, inaccuracy in product demand forecasting can simultaneously impact on both Lean and Green practices. As Interviewee 6 stated, “... poor product demand forecasting can generate a great deal of inaccuracy in the forecast of volume loads vehicles move". For example, according to Interviewee 6, "... two customers located at close proximity could have orders which initially require two fully loaded vehicles, then the customers can decrease their orders at short notice, but the LSP would have already dispatched a vehicle for one of these customers, so two half-loaded vehicles are used, which is inefficient in terms of cost and $\mathrm{CO}_{2 \mathrm{e}}$ emissions". The issue is that, with the benefit of hindsight, the orders could have been allocated to one single delivery. Moreover, a product may be close to a stockout status due to poor forecasting, so an extra trip is required to move the goods to the customer. According to Interviewee 3, in some industries, transport costs are a very low percentage of the total product cost, encouraging the customer to put delivery time above transport cost and fuel consumption per product, since vehicle scheduling and routing efficiency can be sacrificed to ensure high service levels and frequent deliveries for the customer. 
In several cases, simultaneous application of Green and Lean activities can have negative or positive impact, depending on the proposed initiative, as Interviewees 6 and 7 stated. If the objective is to increase service levels to improve product quality by having chilled vehicles, this leads to higher costs and higher $\mathrm{CO}_{2 \mathrm{e}}$ emissions. Another significant trade-off exists when shifting cargo from road to rail freight transport, since that can generate reduction in $\mathrm{CO}_{2 \mathrm{e}}$ emissions but causes increases in freight transport cost. Furthermore, as Interviewee 4 mentioned, "... lead-time and inventory levels usually have to be sacrificed when shifting cargo from road to rail transport modes. Similarly, this is always the case when shifting cargo from air to sea; there can be substantial reductions in cost and $\mathrm{CO}_{2 \mathrm{e}}$ ".

\section{Case Study B - Synergies and misalignments between Green and Lean}

According to Interviewees 1, 2 and 3 from company B, there are several synergies between Lean and Green practices. In support of this statement, Interviewee 2 stated: "Lean and Green go hand in hand, even in situations when the customer order is urgent, and the quantity shipped is small". An example of this is optimisation of container handling and movements, which brings reductions in costs and $\mathrm{CO}_{2 \mathrm{e}}$ emissions. Interviewee 3 further provided an example of how very effective logistics service providers will have collaborative arrangements with other LSPs, so small orders can be outsourced to subcontractors. The following quote from Interviewee 3 provides an example of simultaneous application of Lean and Green practices : “... journey time reliability should be kept or improved as long as LSPs keep theirfleet capacity flexible through tactical outsourcing of some customer deliveries to cope with seasonal volume fluctuations, since such an innovation has led to more dynamic and flexible transport planning and execution; because when capacity is not available in-house or the vehicle available needs to return empty to the distribution centre, there is always a subcontractor that can do the trip in a more responsive and cost-effective manner, generating significant reductions in freight Tonne-Km and delays within all our transportation networks". Interviewee 2 was in accord with this view by stating that "... effective collaboration among cargo carriers which specialise in different transport modes can generate cost and environmental efficiency gains across multiple logistics networks".

The role of ICT in simultaneous application of Lean and Green practices is critical, as suggested by Interviewee 1 . Their company has adopted an innovative ICT system which enables dynamic transport planning of their networks and inter-company collaboration arrangements with other LSPs. These initiatives have led to Leaner and Greener transport operations, since they have generated reductions in the number of trips, drivers and vehicles they use, as well as fuel consumption. Moreover, implementing this approach has helped them to run full-loaded vehicles, fewer miles, and improved availability when pallets are ready to be loaded at distribution centre dispatch bays. Interviewee 1 provided another example of effective consolidation of customers' volume orders and the adoption of cross-docking distribution facilities that can generate reductions in fuel consumption, warehouse energy consumption, and cost (fewer drivers, reduced fuel cost and warehouse electricity bills), since consolidation and deconsolidation of freight can optimise logistics key performance indicators, such as warehouse product fill per square metre and vehicle utilisation.

In addition, interviewee 1 also stated - "their company has implemented manufacturing and packaging postponement supply chain strategies in conjunction with their global customers". Such an initiative has generated reduction in packaging, as well as better fill ratios (kilograms per square metre) in their container shipping and regional transportation networks, which has led to several economic and environmental benefits. Having the packaging closer to the market 
has led to more accurate demand forecast and reduced product obsolescence, which has been particularly beneficial in food supply chains in terms of achieving significant food waste reduction. Furthermore, transporting goods in bulk up to the decoupling point of their customer supply chains has enabled company B to run more cost-effective and energy-efficient warehousing and transportation operations (e.g. no need to rush the order through air freight transport but use local road network for transportation). Another solution, mentioned by Interviewee 2, is the adoption of green vehicle technology that makes vehicles lighter and more aerodynamic. This renders transport greener and more cost-effective simultaneously, because fuel consumption can be reduced by $5 \%$ as a consequence of better optimised unit load-Km.

In spite of several innovative examples of practice in Case B leading to simultaneous implementation of Green and Lean practices, there were also examples of misalignment between two practices in Case B. According to Interviewees 2 and 3, radical Green solutions can increase the cost of logistics operations. For example, Interviewee 2 stated that “... several vehicle technologies, such as electric vehicles, biofuels and hybrid engines, are still more expensive and have longer pay-back period than their more used alternatives, even though such technologies are very effective at reducing $\mathrm{CO}_{2 e}$ emissions, they need to be developed further to make them Leaner for the business". Interviewee 3 agreed with the views shared by Interviewee 2. Another very important misalignment is the technical feasibility of some vehicle technologies, as Interviewee 3 rightly pointed out, "... if one thinks about the need to manufacture and purchase more vehicles". Interviewee 4 also stated that although electric vehicles are recommended in the logistics industry as an effective measure for the reduction of $\mathrm{CO}_{2 \mathrm{e}}$ emissions, Case $\mathrm{B}$ is considering the wider adoption of this vehicle technology with caution, since the electrification of logistics networks moves the energy generation required for moving vehicles from the vehicles themselves to an electricity generation plant, and all depends on how much Greener and Leaner is the energy used to charge the vehicles.

Interviewees 1 and 2 highlighted that there is an increase in the risk of operational failures occurring when LSPs share vehicles and deliver multiple orders for multiple customers; then, the delivery process can become less Lean, since service levels and journey time reliability are sacrificed at the expense of cost optimisation. Furthermore, Interviewee 3 emphasised that recycling cardboard packaging waste is very Green, but it is very labour intensive, so it does bring increases in costs, which in many cases, customers are not willing to absorb. Interviewee 3 said that "... the biggest challenge for logistics operations and supply chains in their journey to become Green and Lean is to change the mind-set of all their company's external stakeholders to allow the financial planning of Green innovations to be more long-term". Interviewee 4 also emphasised that in grocery retail distribution environments, most deliveries are executed between 5am and 9am, which generates the need for more vehicles, since the majority of trucks are idle for at least 18 hours of the day. Thus, if retailers make their delivery patterns smoother through the working day, the overall utilisation of vehicles could improve; therefore, materials used for manufacturing trucks could be reduced as a result of a reduction in the number of vehicles purchased for a given network.

\section{Case Study C-Synergies and misalignments between Green and Lean}

In Case $\mathrm{C}$, a range of synergies between Green and Lean were found. Highly efficient distribution of online orders can bring cost savings and reduction in $\mathrm{CO}_{2 \mathrm{e}}$ emissions, as Interviewee 1 pointed out. Interviewee 1 stated that “... responsive distribution centres enabled by automation can ensure products are ready for dispatch at the distribution centre docks, so the customer load order is correct, preventing the need for the case study company $C$ to run 
extra trips when shipment quantities are not correct". Interviewee 2 agreed with the view stated by Interviewee 1 by pointing out that automation and process control technology can significantly reduce dispatch errors in distribution centres. Hence, such technologies have a positive knock-on effect on transport efficiency. Interviewee 3 also explained that their company recently redesigned one of their distribution centres with the purpose of making their layouts more efficient and time compressing. This process improvement made their warehouses much Leaner and also reduced distribution centre response time, so the distribution centre operation is now more responsive and more energy efficient per stock unit handled. Interviewee 3, the supply chain director of company $\mathrm{C}$, confirmed that the implementation of warehouse automation technology in their two recently built distribution centres has brought many benefits to their supply chain. Some of these benefits relate to Lean, such as a more efficient product handling ratio per hour and the adoption of more responsive JIT systems in their supply chain. The company has also linked benefits to Green practices, including reduction in the total warehousing space, thereby resulting in decrease in the electricity consumption of their network. These are examples of process innovation that has helped distribution centres to become more responsive to orders from different local markets, which also makes transportation much more fuel efficient and can substantially reduce the ratio of $\mathrm{CO}_{2 \mathrm{e}}$ emissions per product stored/delivered.

Meanwhile, Interviewee 3 stated that, “... improvements in the optimisation of distribution networks via the adoption of advanced ICT technologies can result in greater service levels and more efficient deliveries offered to customers, since transportation can be planned in a more efficient manner by using live updates on whether vehicles are delayed or early; therefore, deliveries can be re-planned in a dynamic manner". Such technology has enabled case study company $\mathrm{C}$ to increase vehicle utilisation and reduce vehicle mileage, and as a result, bring significant reduction in cost and $\mathrm{CO}_{2 \mathrm{e}}$ emissions.

Interviewee 1 stated that "... legislation is the single main driver for firms to adopt specific Green distribution measures; an example of that is the fact that battery and electronics recycling must be done by law; although recycling electronic products and batteries at the company $C$ warehouses is beneficial for the environment, it brings an additional cost to company C'. Moreover, new vehicle emissions legislation imposed on car makers can bring significant cost and emissions savings in the future, which will be very beneficial for companies distributing freight, since lighter and greener vehicles can be more cost-effective and carbon efficient. Interviewee 4 highlighted that "... we are planning to replace all the delivery fleet that operates in the Greater London Area with electric vans with the aim of achieving a very significant reduction in emissions per pallet. This initiative is expected to generate substantial environmental benefits and long-term cost savings". If a decision maker takes a supply chain perspective, the adoption of the vast majority of Green innovations generate waste minimisation, cost reduction and carbon efficiency gains. Interviewees 1 and 3 were in accord with Interviewee 4's statement: “... supply chains can adopt innovative solutions to generate Green and Lean improvements, e.g. reductions in $\mathrm{CO}_{2 e}$ emissions, cost and packaging waste". Furthermore, Interviewee 3 said that the adoption of advanced inventory management software can enhance the accuracy of product demand forecast; hence, waste can be reduced through having accurate supplier orders, and as a result, freight transport cost and $\mathrm{CO}_{2 \mathrm{e}}$ emissions can be reduced by moving supplier loads in a more efficient manner.

Another example of innovation exhibited by company $\mathrm{C}$ was in their demand management strategy. The majority of customer orders in company $\mathrm{C}$ are placed during the weekends, causing sharp delivery peaks on weekends. Company $\mathrm{C}$ can achieve full loads on weekends, 
but only half-full loads during week days. Applying demand management strategy to influence customer demand, company $\mathrm{C}$ has recently implemented a premium price system for weekend deliveries, so customers are encouraged to order deliveries during week days as well and vehicles can be loaded in a more cost and carbon efficient manner. Interviewee 1 also shared with the research team that company $\mathrm{C}$ has the plan to use a set of common logistics service providers they have with other online retailers with the aim to gain efficiency in the delivery process, and as a result, reduce miles and maximise vehicle utilisation within their network.

Interviewees from company $\mathrm{C}$ suggested several misalignments or trade-offs related to the adoption of Green and Lean. Interviewee 1 explained that company $\mathrm{C}$ has no physical stores and only delivers products to customers' homes; as a result, company $\mathrm{C}$ is responsible for the recycling and disposal of waste batteries and electric products, leading to reduction in profits. On that specific point, Interviewee 4 stated that "... company $C$ is receiving a great deal of pressure from external stakeholders, such as the UK government and customers, to increase the ratio of recycled waste against products sold, this issue can bring significant economic losses to company $C$, if they are not addressed appropriately". However, Interviewee 2 emphasised that the company $C$ waste management LSP has replaced old vehicles with new large goods vehicles (LGV) which perform far more efficiently in the delivery of recyclable waste; therefore, the customer does not absorb those costs. Interviewee 2 also mentioned that new regulations on refrigerant gases generate the need for company $\mathrm{C}$ to absorb most of the costs required to implement this type of refrigeration system. Another misalignment highlighted by Interviewee 3 is the trade-offs between stock replenishment frequency and transport efficiency, emphasising that "from an operational perspective, it is more efficient to have one-off replenishments a week, but such a replenishment frequency can reduce the product life at the customer end".

\section{Discussion of the findings}

This section presents a discussion on the findings gathered from cases A, B and C linked to synergies and misalignments in their Lean and Green practices and compares the findings with secondary literature. We divide the discussion into two sections on synergies and misalignments.

Synergies - evidence gathered from cases against the literature

The main synergistic element driving simultaneous application of Lean and Green practices across Cases A and B are cost and customers pull. Carvalho et al. (2011), Garza-Reyes et al. (2016), and Colicchia et al. (2017) state that the objective of both Lean and Green regarding transportation is to reduce truck miles to shorten the lead time save cost (Lean) and reduce $\mathrm{CO}_{2 \mathrm{e}}$ emissions (Green). All three companies used advanced vehicle routing and optimisation software to achieve the aforementioned objectives of reduced truck miles leading to efficiency gains and emission reduction.

The LSPs (Cases A and B) demonstrated the benefits from close collaboration with clients/ customers/ suppliers resulting in improved information visibility and sharing, which is also supported by academic literature (Sanchez-Rodrigues et al., 2015; Martinez-Jurado \& MoyanoFuentes, 2014; Garza-Reyes et al., 2016), although the power dynamics make it difficult for LSPs to be heard. Logistics is typically a customer-driven sector affected by customeroriginated fluctuations that are countered using flexible mechanisms such as postponement principle (Purvis et al., 2014) implementation in Cases A and B. Such advanced mechanisms can only be achieved through 'effective collaboration' (Martinez-Jurado \& Moyano-Fuentes, 2014; Garza-Reyes, 2015). For instance, the planning of complex logistics systems is 
increasingly characterised as a collaborative process with various participants involved, including the supplier, the customer, and several companies providing logistics functions across the supply chain (Mollenkopf et al., 2010; Colicchia et al., 2017).

Another important synergy found in Cases B and C was cost reduction. Previous research on Lean and Green outlines similar findings regarding the importance of cost minimisation through innovation in process, resulting in waste reduction when implementing Lean and Green in supply chains (Mollenkopf et al., 2010; Carvalho et al., 2011; Dües et al., 2013; Dhingra et al, 2014; Garza-Reyes, 2015; Piercy \& Rich, 2015; Cherrafi et al., 2017). The postponement of packaging operations closer towards the customer end is an example of applying innovative Agile concept that is typically applied by companies to manage demand uncertainty and retain flexibility in managing supply chain orders (Purvis et al., 2014). Cases A and B applied packaging postponement strategy to reduce product obsolesce, packaging materials cost and vehicle running cost, in addition to other savings linking physical materials waste, warehousing-based energy consumption and freight transport carbon emissions.

Another example of process innovation provided by Case B was outsourcing small orders of work to their close network of subcontractors who help in minimising cost and emissions simultaneously. Most participants from Case A stated that the adoption of Lean and Green simultaneously can lead to cost reduction. Similarly, the vast majority of participants from Cases B and C stated that, most of the time, cost reduction is a desirable outcome of Green innovation. Financial benefits are one of the main arguments and incentives for companies to implement Green approaches (Zhu, et al., 2010), although changes in regulations and customer pressure also force companies to adopt Green practices (Mollenkopf et al., 2010; Garza-Reyes, 2015; Colicchia et al., 2017).

The adoption of programmes that aim to reduce carbon emissions in Cases A, B and C, such as use of light vehicles, hybrid or electric vehicles, vehicle optimisation routing software, improvement in warehouse layout and demand management (Case $\mathrm{C}$ example) provides strong evidence on how reductions in $\mathrm{CO}_{2 \mathrm{e}}$ emissions can also lead to minimisation of cost and improvement in delivery time. This finding is in accord with literature stating that Green practices facilitate achievement of Lean objectives (Franchetti et al., 2009; Carvalho et al., 2011; Garza-Reyes, 2015; Garza-Reyes et al., 2016). As some interviewees from Case A highlighted, reductions in $\mathrm{CO}_{2}$ emissions can bring network efficiency gains through minimisation in the number of vehicles and miles run by the company A network. Similarly, two of the three participants from Case B emphasised that efficiency gains achieved in the container handling and movement processes have led to cost and $\mathrm{CO}_{2 \mathrm{e}}$ reductions across all customer accounts held.

Lean and Green overlap in certain supply chain attributes, such as capacity surplus, integration level, inventory level, production lead time or transportation time and represent synergies in these cases (Carvalho \& Cruz-Machado, 2009; Carvalho et al., 2011). As Tacken et. al (2014), Garza-Reyes et al. (2016) and Colicchia et al. (2017) demonstrate, several measures can be adopted to make logistics operations Greener and Leaner, such as modal shift, logistics network optimisation, network consolidation and inter-company collaboration. Similar practices were observed when presenting the findings from three cases. Examples of range of process innovation from Case $\mathrm{C}$ clearly help to understand the synergistic relationship between Lean and Green practices, as evidenced in literature (Garza-Reyes et al., 2016; Colicchia et al., 2017; Tacken et al., 2014), such as use of automation and advanced ICT technologies for order sorting 
in a warehouse for accurate delivery of ordered goods to improve service levels, order fulfilment; redesign of warehouse layout to reduce picking time and improve in-bound logistics efficiency; demand management by increasing the premium for weekend deliveries; sharing of fleets with other online retailers to gain efficiency in the delivery process, and as a result, reduce miles and maximise vehicle utilisation within their network.

Meanwhile, according to some interviewees from Cases A and B, the simultaneous adoption of Green and Lean is considered as having a positive influence on quality or at least a neutral effect. Researchers have found the concurrent implementation of Green and Lean can bring improvements in process quality, and emphasise that organisations not undertaking a LeanGreen journey do not perceive the same effects on quality (Bergmiller \& McCright 2009; Alves \& Alves, 2015; Piercy \& Rich, 2015; Cherrafi et al., 2017). However, these authors stress that the implementation of Green and Lean must be conducted simultaneously in order to achieve the full potential and benefits from both. Table 4 summarises the findings gathered from Cases $\mathrm{A}, \mathrm{B}$ and $\mathrm{C}$ in contrast to previous literature.

Table 4 - Synergies between Green and Lean found in the cases and literature review

\begin{tabular}{|c|c|c|c|}
\hline Literature Review & Case A & Case B & Case C \\
\hline $\begin{array}{l}\text { Positive impact on bottom-line (Zhu, et al., } \\
\text { 2010; Mollenkopf et al., 2010, Tacken et al., } \\
\text { 2014; Garza-Reyes et al., 2016; Colicchia et } \\
\text { al., 2017) }\end{array}$ & Cost savings & Cost savings & Cost savings \\
\hline $\begin{array}{l}\text { Main Driver: Process capacity, time, cost, } \\
\text { customer, CSR (Carvalho \& Cruz-Machado, } \\
\text { 2009; Dües et al., 2013; Dhingra et al., 2014; } \\
\text { Garza-Reyes, 2015) }\end{array}$ & $\begin{array}{l}\text { Main driver: } \\
\text { Cost reduction, } \\
\text { customer pull } \\
\text { and CSR }\end{array}$ & $\begin{array}{l}\text { Main driver: } \\
\text { Cost reduction } \\
\text { and customer } \\
\text { pull }\end{array}$ & $\begin{array}{l}\text { Main driver: Cost } \\
\text { Reduction }\end{array}$ \\
\hline $\begin{array}{l}\text { Positive influence on lead time reduction } \\
\text { (Dües, et al., 2013; Piercy \& Rich, 2015; } \\
\text { Pampanelli et al., 2014; Ng et al., 2015; } \\
\text { Cherrafi et al., 2017; Sanchez Rodrigues et al., } \\
\text { 2015) }\end{array}$ & $\begin{array}{l}\text { Time and } \\
\text { Reliability: No } \\
\text { positive } \\
\text { influence }\end{array}$ & $\begin{array}{l}\text { Time and } \\
\text { Reliability: A } \\
\text { positive } \\
\text { influence }\end{array}$ & $\begin{array}{l}\text { Time and } \\
\text { Reliability: Not } \\
\text { mentioned }\end{array}$ \\
\hline $\begin{array}{l}\text { Positive impact on Quality (Bergmiller \& } \\
\text { McCright, 2009; Garza-Reyes, 2015; Piercy \& } \\
\text { Rich, 2015; Cherrafi et al., 2017) }\end{array}$ & $\begin{array}{l}\text { Quality: A } \\
\text { positive } \\
\text { influence }\end{array}$ & $\begin{array}{l}\text { Quality: A } \\
\text { positive } \\
\text { influence }\end{array}$ & $\begin{array}{l}\text { Quality: Not } \\
\text { mentioned }\end{array}$ \\
\hline $\begin{array}{l}\text { Improvement in supplier relationship } \\
\text { (Mollenkopf et al., 2010; Dües et al., 2013; } \\
\text { Garza-Reyes, 2015; Martinez-Jurado \& } \\
\text { Moyano-Fuentes, 2014; Simons \& Mason, } \\
\text { 2003; Simpson \& Power, 2005; Cabral et al., } \\
\text { 2012; Garza-Reyes et al., 2016) }\end{array}$ & $\begin{array}{l}\text { Yes: good } \\
\text { relationship } \\
\text { with sub- } \\
\text { contractors to } \\
\text { improve on cost } \\
\text { reduction and } \\
\mathrm{CO}_{2 \mathrm{e}} \text { emission }\end{array}$ & $\begin{array}{l}\text { Yes: good } \\
\text { relationship } \\
\text { with sub- } \\
\text { contractors to } \\
\text { improve on cost } \\
\text { reduction and } \\
\mathrm{CO}_{2 \mathrm{e}} \text { emission }\end{array}$ & $\begin{array}{l}\text { As Case C managed } \\
\text { their own logistics } \\
\text { for delivery to } \\
\text { customers, no } \\
\text { mention of supplier } \\
\text { relationship }\end{array}$ \\
\hline $\begin{array}{l}\text { Process Innovation (Florida, 1996; Piercy \& } \\
\text { Rich, 2015; Colicchia et al., 2017; Negra et } \\
\text { al., 2017; Garza-Reyes et al., 2016; Colicchia } \\
\text { et al., 2017; Tacken et al., 2014) }\end{array}$ & $\begin{array}{l}\text { Several } \\
\text { examples of } \\
\text { Process } \\
\text { Innovation } \\
\text { demonstrated }\end{array}$ & $\begin{array}{l}\text { Several } \\
\text { examples of } \\
\text { Process } \\
\text { Innovation } \\
\text { demonstrated }\end{array}$ & $\begin{array}{l}\text { Process innovation } \\
\text { demonstrated, } \\
\text { though automation } \\
\text { and process control } \\
\text { technology }\end{array}$ \\
\hline
\end{tabular}




\section{Misalignments - evidence gathered from cases against the literature}

The misalignments found in the three cases run in this research are shown in Table 5. This section compares the misalignments found with inputs from previous research studies. Cases $\mathrm{A}, \mathrm{B}$ and $\mathrm{C}$ show evidence that the main misalignment in implementing Lean and Green simultaneously is that, in the short term, there are considerable increases in cost. Most interviewees from Cases A and B highlighted cost as a key barrier to the simultaneous adoption of Green and Lean (Rothenberg et al., 2001; Mollenkopf et al., 2010; Garza-Reyes, 2015; Colicchia et al., 2017), since, in many cases, an investment is necessary for adoption of radical, green innovations, e.g. upgrading of technology, use of lighter vehicles and hybrid/electric vehicles. Examples from Case A, regarding adherence to service level agreement taking priority over $\mathrm{CO}_{2 \mathrm{e}}$ reduction, clearly shows the misalignment where focus is more on timely delivery to meet Lean objective at the cost of compromising Green objectives. Another example from Cases A and B is linked to the use of intermodal transport, which is known to improve efficiency and $\mathrm{CO}_{2 \mathrm{e}}$ reduction (Colicchia et al., 2017; Venkat \& Wakeland, 2006; Verrier et al., 2014). In the selected Case A, changing transportation mode from road to rail may help to simultaneously deliver service on-time with fewer emissions but result in high freight cost.

Furthermore, the interviewees from Case $\mathrm{C}$ see cost as a synergy rather than a misalignment of Green and Lean, but the only exception to that is reverse supply chain activities, such as recycling. Also, most of the interviewees from Case $\mathrm{C}$ see the customer either as a synergy or misalignment, since convenience and cost in the order delivery process can bring contrasting outcomes (Mollenkopf et al., 2010). Interviewees from Case $C$ warn that, in terms of some Green practices the company needs to implement, such as recycling of batteries and unsold electric goods, all the cost needs to be absorbed without the company perceiving any financial benefits. Collecting batteries and electronic products from customer homes increases operational costs and these have been passed to Case $\mathrm{C}$ due to legislation and their own concern to be seen as a good CSR company. The above example from Case $\mathrm{C}$ differentiates between logistics and core manufacturing operations when implementing Lean and Green simultaneously. In core manufacturing operations, companies have control over their processes and thus synergistic application of Lean and Green through waste and energy reduction is feasible. On the other hand, in logistics operations, companies are dependent on customers to organise their loading and routing of fleets, which does not help companies in achieving Lean and Green objectives (Tacken et al., 2014; Garza-Reyes et al., 2016).

Demand uncertainty from customer end results in significant impact on service level, cost, and $\mathrm{CO}_{2 \mathrm{e}}$ emissions. For example, regarding journey time reliability, one of the interviewees from Case B mentioned that when errors occur in the delivery processes due to demand uncertainty, regarding the time, quantity, or location of a delivery, this can cause the network to run more miles, thus causing misalignment, resulting in increase in cost and $\mathrm{CO}_{2 \mathrm{e}}$ emissions (Dües, et al., 2013; Venkat \& Wakeland, 2006; Simpson \& Power, 2005). As Dües, et al. (2013) found, minimisation of errors in the execution of logistics can lead to better optimised logistics networks. This scenario worsens if LSPs are dealing with extended supply chains. More extended supply chains find difficulty in adopting Green and Lean simultaneously, due to there being conflictive effects that Green could bring to the cost of a wide variety of stakeholders, such as suppliers, manufacturers, retailers and logistics service providers (Venkat \& Wakeland, 2006; Simpson \& Power, 2005). 
Table 5 - Misalignments between Green and Lean found in the cases and literature review

\begin{tabular}{|c|c|c|c|}
\hline Literature Review & Case A & Case B & Case C \\
\hline $\begin{array}{l}\text { Cost as a key barrier to Lean and } \\
\text { Green integration (Venkat \& } \\
\text { Wakeland, 2006; Tacken et al., } \\
\text { 2014; Mollenkopf et al., 2010; } \\
\text { Garza-Reyes, 2015; Colicchia et } \\
\text { al., 2017) }\end{array}$ & $\begin{array}{l}\text { Increased cost in the } \\
\text { short-term due to } \\
\text { Green vehicles }\end{array}$ & $\begin{array}{l}\text { Increased cost in } \\
\text { the short-term due } \\
\text { to Green vehicles }\end{array}$ & $\begin{array}{l}\text { Cost of certain } \\
\text { green initiatives } \\
\text { very high, e.g. } \\
\text { recycling batteries } \\
\text { from customers }\end{array}$ \\
\hline $\begin{array}{l}\text { Just-in-Time (Lean approach) and } \\
\text { carbon emissions stay in conflict } \\
\text { (Rothenberg, et al., 2001; Tacken } \\
\text { et al., 2014; Garza-Reyes,2015) }\end{array}$ & $\begin{array}{l}\text { Yes, e.g. adherence to } \\
\text { service level } \\
\text { agreement taking } \\
\text { priority over } \mathrm{CO}_{2 \mathrm{e}} \\
\text { reduction }\end{array}$ & $\begin{array}{l}\text { Yes, e.g. JIT } \\
\text { delivery can cause } \\
\text { network to run } \\
\text { more miles, } \\
\text { resulting in increase } \\
\text { in } \mathrm{CO}_{2 \mathrm{e}} \text { emissions }\end{array}$ & $\begin{array}{l}\text { Yes, e.g. trade- } \\
\text { offs between } \\
\text { stock } \\
\text { replenishment } \\
\text { frequency and } \\
\text { transport } \\
\text { efficiency }\end{array}$ \\
\hline $\begin{array}{l}\text { Contradictions in waste: time \& } \\
\text { stock versus } \mathrm{CO}_{2 \mathrm{e}} \text { and customer } \\
\text { (Dües, et al., 2013; Venkat \& } \\
\text { Wakeland, 2006; Simpson \& } \\
\text { Power, 2005) }\end{array}$ & See above example & $\begin{array}{l}\text { See above example; } \\
\text { Delivery in the } \\
\text { same time frame } \\
\text { requires many } \\
\text { vehicles }\end{array}$ & $\begin{array}{l}\text { See above } \\
\text { example }\end{array}$ \\
\hline $\begin{array}{l}\text { Perspective of the nature of the } \\
\text { environment (Franchetti, et al., } \\
\text { 2009) \& conflicting customer } \\
\text { preferences (Dües, et al., 2013; } \\
\text { Tacken et al., 2014) }\end{array}$ & $\begin{array}{l}\text { Variation in customer } \\
\text { order and lack of } \\
\text { visibility of orders } \\
\text { causes misalignment }\end{array}$ & $\begin{array}{l}\text { Variation in } \\
\text { customer order and } \\
\text { lack of visibility of } \\
\text { orders causes } \\
\text { misalignment }\end{array}$ & $\begin{array}{l}\text { Weekend orders } \\
\text { by customers } \\
\text { results in less } \\
\text { vehicle utilisation } \\
\text { during weekdays }\end{array}$ \\
\hline $\begin{array}{l}\text { Change management (Dües, et } \\
\text { al., } 2013 \text {; Piercy and Rich, 2015; } \\
\text { Martinez-Jurado \& Moyano- } \\
\text { Fuentes, 2014) }\end{array}$ & Not mentioned & $\begin{array}{l}\text { Biggest hurdle is } \\
\text { people/employee }\end{array}$ & Not mentioned \\
\hline $\begin{array}{l}\text { End of product-life management } \\
\text { (Dües, et al., 2013; Simson \& } \\
\text { Mason, 2003) }\end{array}$ & Not mentioned & $\begin{array}{l}\text { Cardboard } \\
\text { recycling though } \\
\text { not cost effective }\end{array}$ & $\begin{array}{l}\text { Reverse supply } \\
\text { chain activities } \\
\text { such as recycling } \\
\text { increase cost }\end{array}$ \\
\hline
\end{tabular}

Two misalignments found in Case A and not mentioned by participants from Cases B and C are supply chain visibility and demand forecasting. Instead, participants from companies B and $\mathrm{C}$ emphasise how not having technologies, either related to ICT and/or vehicle improvements, available to the company adopting Green and Lean can hinder the success of this type of programme. Recent research studies emphasise that insufficient supply chain visibility can lead to unnecessary inefficiencies in inventory holding and transportation operations (Ye \& Wu, 2015; Sanchez Rodrigues et al., 2015). Furthermore, the findings gathered from Case A show that lead-time and inventory levels could need to be increased when implementing Lean and Green, since cargo shift from road to rail or water transport can lead to $\mathrm{CO}_{2 \mathrm{e}}$ reduction but increases in delivery time and stock levels. In that sense, participants from Case A state that, in global logistics networks, demand disturbances and supply disruptions can lead to the shift of cargo from sea to air, which can affect negatively the Green performance of the supply chain. As Tacken et al. (2014) and Colicchia et al (2017) stated, at global supply chain level, modal shift can lead to reductions in $\mathrm{CO}_{2 \mathrm{e}}$ emissions but increases in delivery times. 
The participants from Case B also mentioned the difficulty in adopting a JIT delivery model and being Green at the same time. This particular evidence regarding replenishment frequency confirms previous findings obtained by Rothenberg et al. (2001), who state that JIT contradicts Green, particularly in regard to transport-based carbon reduction. Dües, et al. (2013) emphasise that Lean and Green initiatives differ in terms of end of product-life-cycle management and the understanding of waste. According to Lean management, time compression can reduce waste by removing non-value adding activities and reducing stock levels; however, time compression can increase the carbon footprint of transportation (Martinez-Jurado \& Moyano-Fuentes, 2014; Garza-Reyes et al., 2016). Other observations of misalignment between Lean and Green practices observed in Case B were related to: transitioning towards electric vehicle not only adding cost to operations but also raising questions as to whether generating mobility through an energy generation plant is a greener option or not; risk of operational failures occurring when LSPs share vehicles and deliver multiple orders for multiple customers, resulting in the delivery process becoming potentially less Lean, since service levels and journey time reliability are sacrificed at the expense of cost optimisation.

In addition, according to Case $\mathrm{B}$, one of the greatest hurdles companies face when aiming to adopt Green and Lean simultaneously is people, since it is difficult to change people and convince them to try something new, as evidenced in literature (Piercy \& Rich, 2015; MartinezJurado \& Moyano-Fuentes, 2014). People need to see that becoming greener brings tangible benefits to their companies and jobs. Moreover, Mollenkopf et al. (2010) also identified the culture issue and suggested that reducing waste through a change in business practice can be achieved by adaptation of organisational culture and mind-set.

\section{Conclusions}

The objective of this paper is to identify the main synergies and misalignments that need to be considered when adopting Green and Lean practices simultaneously in the context of Logistics operations. The three conveniently selected cases, which include a range of distribution operations, have generated a wide range of evidence. The outcome of the three cases shows that several improvements can be achieved by the simultaneous adoption of Lean and Green practices by a wide variety of logistics operations. In the manufacturing literature, there is ample evidence on the overlaps between Green and Lean; however, logistics networks tend to be open systems and more complex and unpredictable than manufacturing operations. Thus, our study builds on previously published, limited literature on the simultaneous application of Green and Lean practices in the Logistics sector (Garza-Reyes et al., 2016; Colicchia et al., 2017; Esmemr et al., 2010; Verrier et al., 2014; Tacken et al., 2014), and enhances understanding through documented cases on how managers in logistics companies can undertake integration of Lean and Green approaches. The adoption of Green and Lean practices required close collaboration between the LSP and its customers, particularly since technological innovation is key for improving supply chain information visibility and relaxing the trade-offs between Green and Lean. This study found that to be greener and leaner, LSPs need full support from their customers and other LSPs.

It was found that the representatives from the three cases see Lean and Green practices as an opportunity to improve company reputation in the eyes of the customer. There is general accord among the cases that Lean and Green implementation can generate gains in carbon and cost efficiency. Also, the findings show that Lean and Green approaches are conducive to achieving better product quality and service levels for the benefit of the customer, particularly in terms of augmenting product life at the customer end. Furthermore, cases generated evidence in 
relation to the fact that greater journey time reliability in the delivery process can generate benefits for Green and Lean. Evidence from three cases demonstrates how companies innovate, incrementally or radically, in their process and technology to maximise synergy between their Lean and Green practices. Most Green innovations found in the study are incremental. However, the study found that some radical innovations are required for logistics operations to take a step change in the journey towards being truly Green.

Companies do face different challenges and misalignments when adopting Lean and Green practices. The main concern of managers is the perceived increase in costs some Green solutions entail. Two of the main challenges logistics operations face when adopting Green and Lean supply chain models are insufficient information visibility and inaccurate demand forecasting. Furthermore, several Green initiatives have not yet taken off due to some Green technologies not yet being sufficiently mature. Other misalignment identified from the case studies is the risk of operational failure when vehicles are shared among LSPs to deliver products to multiple customers. It was also found that recycling of obsolete electric goods, batteries and packaging waste do not bring cost gains to logistics operations, but improve the environmental footprint of such operations. The findings obtained from this study regarding misalignments between Green and Lean are in accord with previous studies regarding the tradeoffs between delivery frequency and carbon footprint of logistics operations and the need for undertaking full life cycle assessment when companies intend to become Lean and Green (Dües, et al., 2013; Simon \& Mason, 2003).

The findings gathered in this study have a considerable degree of alignment with the core conclusions derived from recent Lean and Green studies published in operations management and supply chain management journals. Similar to the core findings of our paper, Piercy and Rich (2015) concluded that lean operations are aligned with a wide range of green KPIs beyond environmental benefits and lean provides much more than a toolkit and helps organisations to achieve their green targets. Our research is also aligned with the work published by Dhiangra et al. (2015) that focuses on potential applications of Lean and Green to help society make the transition to more sustainable societal patterns. Our paper also found that there are misalignments that should be carefully considered when implementing Lean and Green simultaneously. Cheraffi's (2017) conclusions state that organisations need to go through a challenging and gradual process to achieve a full alignment business model of Green and Lean. Nevertheless, even though our research has considerable alignment with studies published in other literature domains, the applications of the findings we gathered from the logistics sector can be applied to other sectors, only if contextual factors are considered to tune the implementation of Lean and Green practices with the right degree of customisation other sectors need.

Several managerial implications can be derived from this study. The study provides documented evidence for Logistics managers to take strategic decisions on how a synergistic relationship between Lean and Green practices can be derived. The study proposes solutions that can be used to mitigate the barriers a company operating in logistics networks may encounter when implementing Green and Lean simultaneously. It identifies a series of incremental innovations that can be adopted to reduce cost and $\mathrm{CO}_{2 \mathrm{e}}$ emissions, as well as highlighting radical innovation opportunities aligned with Green strategies of logistics operations. The findings show that logistics managers need to combine incremental and radical innovations for their companies to become Green and Lean. At the same time, senior management need to give more time to see the return of investment from the integrated approach. Close and effective collaboration with customers or clients through improved 
information visibility is critical to achieving Lean and Green objectives. Also, initiatives, such as investing in hybrid and electric vehicles and vehicle aerodynamics, require a broader, longterm horizon for logistics companies to see returns on these investments. Here, logistics managers can use simulation models to convince their customers and other LSPs of the benefits of collaboration in terms of fleet sharing and order delivery.

The findings and outcome of this study are a starting point for further research. More in-depth, qualitative study is required to compare practices between the logistics sector and core manufacturing industry to identify the customisation required to apply integrated Green-Lean practices in different sectors. The logistics industry can benefit immensely if research proposes examples of integrated Lean-Green practices when managing logistics in different industries, such as oil \& gas, food \& drinks, automotive, retail, electronics, fashion clothing, etc. Our study can be further extended to include focus on measurement and metrics required for simultaneous application of Lean and Green practices, using survey-based research or modelling based research. For example, we can apply modelling-based research to measure the impact of the customer and corporate image on cost, quality and time (Lean metrics) and Green metrics (such as $\mathrm{CO}_{2 \mathrm{e}}$ emission, electricity consumption, tonne-km). In addition, further studies could focus on the relationship between innovation and Lean and Green practices and performance.

\section{References}

Abbasi, M. and Nilsson, F., 2012. Themes and challenges in making supply chains environmentally sustainable. Supply Chain Management: An International Journal, 17(5), pp. 517-530.

Aguado, S., Alvarez, R., and Domingo, R., 2013. Model of efficient and sustainable improvements in a lean production system through processes of environmental innovation. Journal of Cleaner Production, 47, pp. 141148.

Alves, J.R.X., and Alves,J.M. 2015. Production management model integrating the principles of lean manufacturing and sustainability supported by the cultural transformation of a company, International Journal of Production Research, 51(11), pp.1-14.

Bergmiller, G. G. and McCright, P. R., 2009. Are Lean and Green Programs Synergistic?. Proceedings of the 2009 Industrial Research Conference, Miami (FL).

Blome, C., Schoenherr, T. and Eckstein, D., 2014. The impact of knowledge transfer and complexity on supply chain flexibility: A knowledge-based view. International Journal of Production Economics, 147, pp.307-316.

Cabral, I., Grilo, A., and Cruz-Machado, V., 2012. A decision-making model for lean, agile, resilient and green supply chain management. International Journal of Production Research, 50(17), pp. 4830- 4845.

Capineri, C., Leinbach, T.R. and Gips, D., 2006. Freight transport, seamlessness, and competitive advantage in the global economy, European Journal of Transport and Infrastructure Research, 6(1), pp.23-38.

Carvalho, H., and Cruz-Machado, V., 2009. Integrating lean, agile, resilience and green paradigms in supply chain management. Proceedings of the Third International Conference on Management Science and Engineering Management, pp. 3-14.

Carvalho, H., Duarte, S., and Cruz-Machado, V. 2011. Lean, agile, resilient and green: divergences and synergies. International Journal of Lean Six Sigma, 2(2), pp.151-179

Chapman, R. L., Soosay, C. and Kandampully, J., 2003. Innovation in logistics services and the new business model. International Journal of Physical Distribution \& Logistics Management, 33(7), pp. 630-650.

Chauhan, G., and Singh, T.P., 2012. Measuring parameters of lean manufacturing realization. Measuring Business Excellence, 16 (3), pp. 57-71.

Cherrafi, A., Elfezazi, S., Govindan, K., Garza-Reyes,J.A., Benhida, K., and Mokhlis, A., 2017. A framework for the integration of Green and Lean Six Sigma for superior sustainability performance, International Journal of Production Research, 55:15, pp.4481-4515.

Colicchia, C., Creazza, A., and Dallari, F., 2017. Lean and green supply chain management through intermodal transport: insights from the fast moving consumer goods industry, Production Planning \& Control - The Management of Operations, 28 (4), pp. 1221-1232.

Cudney, E. and Elrod, C., 2011. A comparative analysis of integrating lean concepts into supply chain management in manufacturing and service industries, International Journal of Lean Six Sigma, 2(1), pp. 5-22.

Dhingra, R., Kress, R. \& Upreti, G., 2014. Does lean mean green?, Journal of Cleaner Production, 15(85), pp. 17. 
Dües, C. M., Tan, K. H. and Lim, M., 2013. Green as the new Lean: how to use Lean practices as a catalyst to greening your supply chain, Journal of Cleaner Production, 40, pp. 93-100.

Eisenhardt, K.M. 1989. Building Theories from Case Study research, Academy of Management Review, 14(4), pp.532-550.

Eisenhardt, K.M., and Graebner, M.E., 2007. Theory Building from cases: opportunities and challenges, Academy of Management Journal, 50(1), pp.25-32.

Esmemr, S., Ceti, I.B., Tuna, O., 2010. A simulation for optimum terminal truck number in a Turkish port based on lean and green concept, Asian Journal of Shipping Logistics, 26 (2), pp. 277-296.

Farish, M. 2009. Plants that are green: Toyota's lean manufacturing, Engineering and Technology, 4(3), pp.6869.

Fernie, J., Pfab, F., Marchant, C. 2000. Retail Grocery Logistics in the UK, International Journal of Logistics Management, 11 (2), pp.83-90,

Florida, R. 1996. Lean and Green: The Move to Environmentally Conscious Manufacturing, California Management Review, 39(1), pp.80-105.

Franchetti, M., Bedal, K., Ulloa, J. and Grodek, S., 2009. Lean and Green: Industrial engineering methods are natural stepping stones to green engineering, Industrial Engineer, 41(9), pp. 24-29.

Garnett, T., 2009. Livestock-related greenhouse gas emissions: impacts and options for policy makers, Environmental Science \& Policy, 12(4), pp. 491-503.

Garza-Rayes, J.A. 2015. Lean and green - a systematic review of the state of the art literature. Journal of Cleaner Production, 102, pp.18-29.

Garza-Reyes, J., Villarreal, B., Kumar, V., and Molina Ruiz, P., 2016. Lean and green in the transport and logistics sector - a case study of simultaneous deployment, Production Planning \& Control - The Management of Operations, 27 (15), pp. 1221-1232.

Jones, D., Hines, P., and Rich, R. 1997. Lean logistics, International Journal of Physical Distribution \& Logistics Management, 27 (3/4), pp.153-173

King, A. A. and Lenox, M. J., 2001. Lean and green? An empirical examination of the relationship between lean production and environmental performance, Production an Operations Management, 10(3), pp. 244-256.

Martinez-Jurado, P.J. and Moyano-Fuentes, J. 2014. Lean Management, Supply Chain Management and Sustainability: A Literature Review, Journal of Cleaner Production, 8(5), pp.134-150.

Meridith, J.R., 1998. Building operations management theory through case and field research, Journal of Operations Management, 16(4), pp.439-452.

Miles, M.B., and Huberman, A.M., 1994. Qualitative data analysis: an expanded sourcebook, Thousand Oaks, CA: Sage Publications Inc.

Mollenkopf, D., Stolze, H., Tate, W. L. and Ueltschy, M., 2010. Green, lean and global supply chains. International Journal of Physical Distribution \& Logistics Management, 40(1/2), pp. 14-41.

Negrao, L.L.L., Filho, M.G., and Marodin, G. 2017. Lean practices and their effect on performance: a literature review, Production Planning \& Control- - The Management of Operations, 28(1), pp.33-56.

Ng,R., Low, J.S.C., and Song, B. 2015. Integrating and implementing Lean and Green practices based on proposition of Carbon-Value Efficiency metric, Journal of Cleaner Production, 95, pp.242-255.

Pampanelli, A. B., P. Found, and A. M. Bernardes. 2014. A Lean \& Green Model for a Production Cell, Journal of Cleaner Production, 85, pp.19-30.

Piercy, N., and Rich, N. 2015. The relationship between lean operations and sustainable operations, International Journal of Operations and Production Management, 35(2), pp.282-315.

Purvis, L., Gosling, J. and Naim, M. M. 2014. The development of a lean, agile and leagile supply network taxonomy based on differing types of flexibility, International Journal of Production Economics, 151, pp. 100-111.

Robson, C., 2011. Real World Research: A resource for users of social research methods in applied settings. 3 ed. West Sussex, UK: John Wiley \& Sons Ltd.

Rothenberg, S., Pil, F. K. and Maxwell, J., 2001. Lean, green, and the quest for superior environmental performance, Production and Operations Management, 10(3), pp. 228-243.

Sanchez Rodrigues, V., Harris, I. and Mason, R., 2015. Horizontal logistics collaboration for enhanced supply chain performance: an international retail perspective, Supply Chain Management: An International Journal, 20(6), pp.631-647.

Saunders, M., Lewis, P. and Thornhill, A., 2012. Research Methods for Business Students. 6 ed. Harlow, New York: Pearson.

Simons, D., and Mason, R., 2003. Lean and green: doing more with less, International Commerce review: ECR Journal 3 (1), pp. 84-91.

Simpson, D.F., and Power, D.J., 2005. Use the supply relationship to develop lean and green suppliers, Supply Chain Management: An International Journal, 10 (1), pp.60-68. 
Slack, N., Brandon-Jones, A., and Johnston, R., 2013. Operations Management, seventh ed. Pearson Education Ltd, Harlow, UK.

Tacken, J., Sanchez-Rodrigues, V., and Mason, R., 2014. CO2 measurement and reduction initiatives applied within the German logistics sector, International Journal of Logistics Management 25 (1), pp. 5-17.

Thanki, S.J., and Thakkar, J.J. 2016. Value-value load diagram: a graphical tool for lean-green performance assessment, Production Planning \& Control - The Management of Operations, 27(15), pp.1280-1297.

Tomelero,R.L., Ferreira, J.C.E., Kumar, V., and Garza-Reyes, J.A. 2017. A lean environmental benchmarking (LEB) method for the management of cutting tools, International Journal of Production Research, 55(13), pp.3788-3807.

Venkat K., Wakeland, W., 2006. Is lean necessarily green?; Pdf from Website. In: Proceedings of the 50th Annual Meeting of the ISSS, ISSS 2006 Papers, accessed via http://www.cleanmetrics.com/pages/ISSS06IsLeanNecessarilyGreen.pdf; (accessed on 20/06/2017).

Verrier, B., Rose, B., Caillaud, E., and Remita, H., 2014. Combining organizational performance with sustainable development issues: the green and lean project benchmarking repository, Journal of Cleaner Production, 85, pp. 83-93.

Wu, Y-C (2004), Effective Lean Logistics Strategy for the Auto Industry, International Journal of Logistics Management, 13 (2), pp. 19-38.

Ye, Y. and Wu, Y., 2015. 4PL Suppliers Evaluating Indicator System Based on Grey Correlation Model, Open Cybernetics \& Systemics Journal, 9, pp.816-820.

Yin, R.K. 2014. Case Study research: Design and methods. $5^{\text {th }}$ edition, Thousand Oaks, CA: Sage Publications Inc.

Zhu, Q., Geng, Y., Fujita, T. and Hashimoto, S., 2010. Green supply chain management in leading manufacturers case studies in Japanese large companies, Management Research Review, 33(4), pp. 380-392. 


\section{Appendix 1 - Extract from the Interview protocol}

1) Could you please describe your role, expertise and experience?

2) To what extent have lean practice played a role in streamlining your supply chain?

- Please give recent examples of efficiency improvement in your supply chain.

- How the improvement was delivered? Who was involved? And the tools used to streamline your supply chain processes.

- How many Lean projects have been conducted so far and benefits realised from those projects? Please give examples from two recent projects where you were directly leading the project or was part of the project team.

3) What is the motivation to implement Green initiatives within your organisation and supply chain?

- Is Green practices aligned with your CSR strategy? Give examples of green practices recently implemented that was a CSR drive.

- Is Green practices influenced by customer demand? Share examples of practices implemented as a result of customer demand.

- Cost reduction in the operations and supply chain was the main drive to implement green practices. If yes, please share examples of recent practices.

- Would you like to share any other motivational factor that led to Green practice implementation in the company?

4) To what extent implementing green innovation practice help your company to achieve expected target?

- In your opinion, do you see any relationship between green practice implementation and process, product, or technological innovation? If yes, please share example of process, product, and technological innovation. If no, why do you perceive innovation is not the result of green initiatives

- Share examples from recent changes in your warehousing policies, procedures, and loading trucks

- Share examples of how customer orders are taken and delivered. Has there been any changes to improve order visibility from customer or suppliers end?

5) Which are the main synergies between lean and green the supply chain?

- Please share an example of Lean initiatives within your warehousing and distribution process.

- Do you see improvement in efficiency and waste reduction had any impact on green metrics such as $\mathrm{CO}_{2 \mathrm{e}}$ emission, energy usage, etc? If yes, could you please elaborate and explain with example the condition/scenario that facilitate in efficiency improvement and $\mathrm{CO} 2$ reduction.

- Please provide information about your relationships with other carriers. How consolidation of orders are managed?

- Please share examples of recent process or technological innovation in the company that had an impact on efficiency of operations (such as reduction in cost or lead time of delivery). How does that innovation impact on the green metrics?

- Please share examples of recent process or technological innovation in the company that had an impact on Green metrics (such as reduction in energy usage, $\mathrm{CO} 2$ emissions). How does that innovation impact on the efficiency of operations?

6) Which are the main misalignments between lean and green?

- How do you tackle demand uncertainty from customers' end? Please elaborate and give examples on changes required in your routine operations to meet the demand uncertainty

- How the rushed orders are managed and delivered?

- Do you look after end of life care for the product delivered to the customer? What are the challenges encountered in collection process? How does it impact on the cost of recycling operations?

- Do you follow JIT philosophy to deliver orders to customer? If yes, how it is managed? How does it impact on efficiency of operations and green metrics? 